\title{
An accumulated wrong: Roger Casement and the anticolonial moments within imperial governance
}

\begin{abstract}
Taking three moments of governance - executive, legislative, judicial - this paper explains how forms of anticolonial critique were composed and articulated within the general regime of imperial rule. Through the career of Roger Casement, this paper shows how international human rights could develop out of the administration of empires as they monitored and compared the treatment of their own subjects in other imperial spaces. Casement drew particularly on his Irish heritage to identify the expropriation of direct producers as the basis of colonial rule. For Casement, colonialism was coeval with the destruction of native life. This was a far more systematic critique than was typical in commentary on the evils of colonialism. It finally impelled Casement into open rebellion giving him one last opportunity, from the dock as a convicted traitor, to make public an anticolonial epistemology that challenged the legitimacy of imperial sovereignty.
\end{abstract}

Keywords

Anticolonial nationalism; Roger Casement; Colonialism; Empire; Ireland

The contribution of radical thinkers to the criticism of imperialism from the last half of the nineteenth century has been highlighted by historians such Bernard Porter and Gregory Claeys. Indebted though we are to this work, our concern here is less with this genealogy of ideas than with the practical elaboration of anticolonial criticism within the spaces of colonial governance. While scholars draw upon the contents of parliamentary debates, blue book inquiries, and 
judicial reviews in studies of anticolonial movements, less attention has been paid to the spaces of governance themselves as distinctive sites of anticolonial praxis. ${ }^{1}$ The executive, legislative and judicial branches of governance were each engaged with colonialism. Each had its own sites, discourses and geographies and on every surface we find the fissures and cracks that register the fundamental fragility of colonial power. One set of vulnerabilities was produced by the tensions between legitimation and publicity, and this set of anticolonial possibilities could be made manifest even at the heart of empire. The spatial complexity of colonial discourse is noted in much recent anthropology and historical geography, leading Catherine Nash to remark on colonialism's 'complex, shifting and ambiguous social relations', acknowledging that its power was contested both centre and periphery. Similarly Alan Lester and Fae Dussart point to the networks of resistance and solidarity forged between Aboriginal people and their metropolitan allies. ${ }^{2}$ Building on this critical work we view the structures and processes of governance as ripe for repurposing, and in some cases capable of elaborating a powerful critique of colonialism.

As part of the executive, British colonial administration involved many agencies and it was formally answerable to parliament through questions to a responsible minister, calls for publication of official correspondence, the commissioning of inquiries, and the publication of reports from appointed committees. Moreover, the legislative function of parliament is practised across a range of sites including its debating chambers, committee rooms and conferences, not to mention epistolary and less formal communicative networks that are central to governmental deliberation. Similarly, judicial power includes sites of custody, interrogation, public hearing, incarceration and execution. Throughout, the power relations between the coloniser and the colonised are uneven, although at many of these sites of colonial power a certain (circumscribed) publicity and voice might be exercised by subalterns and their supporters. This paper attends to the anticolonial public voice of Roger Casement as it was expressed in and through many of these sites. 
Casement was born in 1864 into a Protestant family in Sandycove, County Dublin. ${ }^{3}$ From 1883 to 1891, he was employed by commercial ventures in West Africa. In 1892 he began work for the British Foreign Office and from 1895 as British consul. With interruptions for leave and recuperation, he served in this way until 1913 when he retired on medical grounds at the age of 49. ${ }^{4}$ Knighted for his service, the highlights of his official career were the reports and campaigns exposing the abuse of indigenous labour in rubber extraction in Congo - based on a journey in 1903, published as a report in 1904 - and the Amazon - based on visits of 1909-1910, a report submitted in 1911 and published in 1912. In retirement, he devoted himself to the cause of Irish independence, organizing gun running, recruiting for the Irish Volunteers, fund-raising in the United States, and, with the outbreak of the First World War, soliciting German support for an independent Irish state. ${ }^{5}$ Apprehended after having been landed near Tralee from a German submarine, he was taken to London, put on trial for treason, and hanged at Pentonville, 3 August 1916 - the last of the sixteen Irish rebels to be executed in that year, and the only one to be hanged.

Our paper begins with colonial administration as part of the executive moment of governance and considers how Casement's experience in Congo was given affective force by his developing understanding of British misrule in Ireland. He began by investigating the abuse of native labour and very soon raised the question in a way that questioned colonial dispossession itself. Next, we turn to the legislative moment of governance and track Casement's evidence within the parliamentary debates they helped animate back in London. We show how a broad assault upon colonialism tout court flourished in spite of the specific constraints of parliamentary protocol. Finally, when Casement moved from colonial critic to anticolonial rebel, he was caught up within the third moment of imperial governance when subjected to the judicial powers of the British state under a charge of treason. Here again, the specific forms of discourse placed constraints upon what could be said or heard and Casement was advised to avoid speaking in his defence for fear that he would be smeared with talk about his queer sexuality. Yet, after 
conviction and in the pause before execution, Casement joined the long tradition of Irish rebels bringing eloquence to the dock of a British courtroom. In his final public address he generalised his anticolonial critique as a gospel of love and solidarity that still echoes in global human rights discourse today.

\section{THE CONGO REPORT}

European colonialism in the Congo is a tale of rapine, slaughter, dissimulation and hypocrisy. ${ }^{6}$ At the Berlin Conference of 1884-1885, the European Great Powers plus the United States of America allowed that, in the interests of suppressing slavery and ensuring free trade for all, the Congo would be administered by a philanthropic company under the personal direction of the king of Belgium. Although a constitutional monarch, Leopold II acted as absolute sovereign in the Congo Free State, even retaining a significant part (Domaine de la Couronne) as a personal domain and part-ownership of some of the companies granted concessions (Figure 1). ${ }^{7}$ Assisting the anti-slavery and aborigine protection societies, the Berlin Conference drew attention to human rights abuses by colonial powers. ${ }^{8}$ In 1897, Charles Dilke, a radical MP and member of the Liberal Party, asked in the House of Commons for a further conference of the Powers to verify if parties had met their treaty obligations of 'preserv[ing] the native populations, [and] improv[ing] their moral and material conditions'. One of Dilke's charges was that the Belgian king had, by secret edict, claimed all 'lands in which there was not private property[,] which was not known to the aborigines'. The vacant lands doctrine (vacuum domicilium) was part of British colonial practice and, as S.J.S Cookey points out, something similar 'soon came to be adopted by [other] colonial powers in Equatorial Africa'. ${ }^{10}$ While the Congo was supposed to have been managed differently, the land grab was actually so extensive that it left indigenous people little beyond the garden plots abutting their villages. ${ }^{11}$ Replying for the government, George Curzon denied that they must 'act as guardians of the public trust imposed on the Congo State'. ${ }^{12}$

In 1898, Casement was sent as consul to the Portuguese colony of Angola. Congo was 
the neighbour to the north, and when the British vice-consul there resigned, Casement was drawn into its affairs. Initially Casement's primary concern was with "'British colonial natives" from West Africa' who had been employed in rubber extraction and had been treated brutally, but he soon began reporting on the rubber trade more generally, citing the testimony of US missionaries who accused the Congo State of murdering those who refused corvée labour. ${ }^{13}$ His trade reports were public documents and were discussed in newspapers, but in parliament the government was not disposed to investigate, suggesting that if US citizens had representations to make those 'would naturally be made through their own Government'. Henry Morton Stanley, who had been repeatedly involved with Belgian and British ventures in the region - two of which were in service of the personal colonial ambitions of Leopold II - spoke up as MP for Lambeth North, interrupting a debate on Uganda to assert that 'there is not one word of truth, not one solid fact, to bear out the statement that the administration of the Congo has been either disastrous or one of evil example'. In reply, citing a paper presented at the Royal Geographical Society, Dilke raised the specific case of Congo State soldiers raiding cattle and women, and killing men in the British protectorate of Uganda. ${ }^{14}$ On this occasion the government was content that the Congo State had promised to 'punish the offenders severely if the offence is brought home to them'. ${ }^{15}$

By 1902, Casement was also acting as US consul for the Congo and an American missionary, William Morrison, brought him reports of violence by Congo State forces against indigenous people. Casement ensured that these documents and allegations reached the Foreign Office. In a memorandum of February 1903, Casement repeated Dilke's arguments for a new meeting of the Powers who endorsed the Berlin Act. He also questioned the right of the Belgian king to take land since the monarch held only treaty rights and not sovereignty. He argued that in the Congo the 'Chief is only the trustee of the tribal family, and his public rights are well defined and strictly limited by popular control', and these rights did not include the alienation of occupied lands. ${ }^{16}$ 
In March 1903 in the House of Commons, Dilke again asked in vain that the signatories to the Berlin Act reconvene. Later that same month, the government described reports of cruelty from consular officers as 'not very complete', and two months later declined to publish Casement's incomplete reports, explaining that 'for various reasons he has been unable to travel to such an extent as to enable him to form anything like a full opinion on the condition of the State'. ${ }^{17}$ On 20 May 1903, evidence from Morrison was read into the record of the House of Commons by Herbert Samuel when moving successfully a motion that the government discuss with the other Berlin signatories 'measures [that] may be adopted to abate the evils prevalent in [the Congo] State'. In the course of the debate, Dilke requested that reports from the consul should be shared with parliament, and on this occasion the government replied that the Congo was very big and that the consul, Casement, was based on the coast. The prime minister, Arthur Balfour, secured the removal from the motion of a 'condemnation' of the Congo government, on the grounds that parliament, in the absence of 'anything in the nature of judicial inquiry', should not base charges 'merely upon statements made in debate'. ${ }^{18}$ Nevertheless, the government was bound by the motion to solicit the assistance of the co-signatories of the Berlin Act in bringing before the Congo government its failures, which it did on 8 August 1903. Yet, as of November 1906 no active support had been offered in response. ${ }^{19}$ At the same time, Casement had requested permission to investigate the upper Congo but, as late as 8 May 1903 when he telegraphed London with his intention of doing so, he was told to wait. ${ }^{20}$ Permission came in early June and, tellingly, Casement later claimed that it only did so 'in view of the debate of May 1903,. ${ }^{21}$

Casement spent two and a half months in the Upper Congo. After a train journey from Matadi to Leopoldville, he spent much of June around Stanley Pool, before departing for the Upper Congo on 2 July. ${ }^{22}$ With a native interpreter, Nsala, and an English Baptist missionary, Albert E. Scrivener, he interviewed refugees who had fled villages now claimed as the private property of the Belgian monarch. ${ }^{23}$ Moving upriver he collected testimony alleging forced labour, 
aborted food cultivation, population loss, rape, torture and mutilation. After spending a few weeks in and around the Domaine de la Couronne, Casement moved further upriver to the lands held by the ABIR Concession Company and spent part of late August and early September at Bongadanga before returning downstream and back to Brazzaville by 15 September. He sought corroboration for the most extreme allegations and on one occasion he confronted a perpetrator with their victim. Taking his lead from journalist Edmund Dene Morel's analysis of Congo trade, Casement consulted trade statistics that showed extensive exports, balanced by minimal imports, with the signal exception of the introduction of more guns. ${ }^{24} \mathrm{He}$ compared what he now found in the Upper Congo with his own observations from 1887, 'and was thus able to institute a comparison between a state of affairs ... when the natives lived ... uncontrolled by Europeans, and that created by more than a decade of very energetic European intervention'. ${ }^{25}$ His letters alarmed staff at the Foreign Office with one official annoyed by his 'exuberant diction' and another disturbed by 'violent diatribes against the Congo State which he has no evidence to support. ${ }^{26}$ He was recalled to London so that he might write up his report under the calming tutelage of civil servants.

From November 1903 until publication in February 1904, the official process of drafting and revision exasperated Casement and he contemplated resigning when the published report omitted the names and locations of African witnesses. He had wanted only the names of the local officials of the Congo State omitted: to prevent reprisals against them, but also so that he might indict a regime rather than individual rogues. ${ }^{27}$ In other cases, the revisions implied that matters reported to and verified by Casement were little more than hearsay. This allowed Constantine Phipps, the Foreign Office representative in Belgium, to temper the force of the report with the observation that although it was an official document, it was merely the opinion of one man. Nevertheless, when the Belgian king attacked Casement's integrity, Phipps suggested that the Foreign Office publish the additional atrocity stories it had reserved on file. ${ }^{28}$ 
Despite the moderating influence of editing from the Foreign Office, Casement's report was severe. He described the military violence used to extract food and other supplies and documented one case where seventeen villagers were killed, forty-eight goats were taken, several houses were torched and sixteen further goats extracted for the repatriation of ten villagers seized as hostages. Following representation from Casement and a claim of compensation to the amount of 3,586 Belgian francs (about $£ 142$ at the time), $950 \mathrm{fr}$. was paid by the officer responsible, although Casement 'could not learn what other form of punishment, if any, was inflicted on this officer'. ${ }^{29}$ There are many specific atrocities recounted in the report but Casement insisted that it was a system he was attacking. Indeed, one British civil servant expressed his irritation by annotating one letter from Casement: 'He has the system on the brain'. ${ }^{30}$ Yet Casement persisted, and a focus upon system became common currency in the full range of discourse upon the Congo 'in Memorials from philanthropic Societies, in communications from commercial bodies in the public press, and in despatches from His Majesty's Consuls' ${ }^{31}$ It was central when the British government wrote to the co-signatories of the Berlin Act in 1904, and was the first item mentioned when the Congo government formally denied that 'the manner in which the [Congo] State is administered involves a systematic regime “of cruelty or oppression"”, ${ }^{32}$ In parliament in 1907 a former foreign secretary described the Congo State as an 'odious system of terrorism?.

Naked coercion, not market exchange, defined King Leopold's rule. In one region, Casement estimated that in return for an annual rubber levy of $£, 52$, trade goods were exchanged to the value of $f 1.25 .{ }^{34}$ At another place, an American missionary reported a conversation with the chief state prosecutor, who admitted that 'The only way to get rubber is to fight for it. ... [T] he amount of rubber is controlled by the number of guns, and not the number of bales of cloth, ${ }^{35}$ The Belgians employed Africans as soldiers but strictly limited their access to ammunition, and the prosecutor added that: 
'Each time the corporal goes out to get rubber, cartridges are given to him.

He must bring back all not used; and for every one used he must bring back a right hand'.... [H]e informed me that in six months they, the State, on the Momboyo River, had used 6,000 cartridges. ${ }^{36}$

In interviews with refugees who had fled the rubber district, Casement was told that some of the African soldiers supplied different proof of slaughter:

[Nkwabali]: The white men told their soldiers: 'You kill only women; you cannot kill men. You must prove that you kill men. So then the soldiers when they killed us' (here he hesitated, and then pointing to the private parts of my bulldog - it was lying asleep at my feet), he said: 'then they cut off those things and took them to the white men, who said: "It is true, you have killed men." ${ }^{37}$

This was violence, so Casement insisted, enacted by soldiers of the State, nominally in the extraction of a legal tax. The tax was paid in rubber and food, 'collected by the agents of a trading firm, and figured as the outcome of their trade dealings with the people'. The violence of the arrangement mocked any pretence to free trade, or to humanitarianism on the part of the Congo Free State. The identity of military and commercial activity was complete. Casement quoted a government circular to its officers that instructed them to police the quality of rubber extraction and enjoined 'constant supervision[, which] is necessary, for as soon as the native notices that the supervision is becoming lax he will lessen his work'. Casement concluded with evident understatement: 'The instructions ... would be excellent if coming from the head of a trading house to his subordinates, but addressed, as they are, by a Governor-General to the principle officers of his administration, they reveal a somewhat limited conception of public duty ${ }^{38}$ In his own correspondence with the governor-general of the Congo State, Casement evoked a 'system of general exploitation of an entire population which can only be rendered 
successful by the employment of arbitrary and illegal force'. ${ }^{39}$

\section{FROM THE CONGO FREE STATE TO ANNEXATION}

The report as it stood in December 1903 was forwarded to the Congo government. They rejected it suggesting both that it was part of a 'campaign of calumny and defamation by the merchants of Liverpool', who wanted the Congo rubber for themselves, and that it had 'no confidence in the Casement report' since neither dates nor locations were given for the mutilations alleged. ${ }^{40}$ The British pressured Leopold II to make public his own commission on Casement's charges and thus, while Casement was in London, his temporary replacement as consul in Congo was required to attend the hearings. Unfortunately the commission held many of its hearings before it permitted the consul to attend, and when its report was published no evidence was provided in support of the exonerations it offered. ${ }^{41}$

Tales of mutilation were a staple of reports from missionaries in the Congo before and after Casement's investigation. One Baptist missionary, Daniel Danielsen, skippered the vessel that took Casement around the Upper Congo, and 'used his journey with Casement to take some of the earliest atrocity photos', which he used after his return to Scotland 'to illustrate his November 1903 lectures' on the Congo. ${ }^{42}$ Another missionary, Joseph Clark, had, in 1901, sent to the governor-general of the Congo State, a photograph of a boy, Mola, who had been maimed to the extent of both hands having been beaten off with rifle butts, and the only acknowledgment received was a notification in the Belgian press 'to the effect that an American missionary was going about with a faked-up photograph ${ }^{43}$ Other missionaries, such as Alice Seely Harris and Danielsen, were largely responsible for the photographs used in Morel's King Leopold's Rule in Africa (1904), Mark Twain's satirical King Leopold's Soliloquy (1905), Arthur Conan Doyle's The Crime of the Congo (1909), and in the hundreds of lectures given by returned missionaries themselves. ${ }^{44}$ Casement included none of these photographs in his reports, although he did deliver some from missionaries to their offices in London. ${ }^{45}$ However, the ways in which 
such photographs established a new standard of verisimilitude was important in the reception of his report; and significantly, in his later investigation into rubber extraction in the Amazonian district of Putumayo, Casement included many of his own. ${ }^{46}$

The executive and legislative moments of governance are linked in part by the discussion in parliament of official reports. Yet publicity was also central to these legislative proceedings, and from the widening of the franchise in 1832 the British parliament became increasingly subject to 'pressure from without'. ${ }^{47}$ During the period when he was writing his report, Casement made contact with journalists and activists. He successfully urged at least some of the missionaries in the Congo to challenge the strategy of their church leaders who had been willing to trade silence for access. ${ }^{48}$ His crucial ally in this public campaign was Morel whom he persuaded to lead it: 'I said that if the Congo question was to be made a living one, it must be taken out of the hands of the Foreign Office and Government and made a people's question and ... I said to you "Thou art the man"!' Morel got the same advice from a civil servant at the Foreign Office: 'If you drop the Congo question, be sure the government will drop it'. With Casement's close help (and indeed a donation of $£ 100$, one-third of his annual income), Morel set up the Congo Reform Association (CRA), 'one of the most effective propaganda instruments in the twentieth century. ${ }^{49}$ In one parliamentary debate, the foreign secretary observed that: 'I think it is not too much to say no external question for at least thirty years moved the country so strongly, so vehemently, as this in regard to the Congo'..$^{50}$ The discussion of the Congo Question in parliament was repeatedly incited by the activism of the CRA, producing no fewer than fourteen debates. ${ }^{51}$ In turn, these parliamentary speeches were reported in the national and international press. During one debate in the House of Lords, the archbishop of Canterbury 'rejoice[d] to think that the speeches delivered here this evening will find an echo outside, ... not least in Belgium itself. ${ }^{52}$ When a royal commission on the civil service put it to him that in connection with your reports, ... important inquiries in regard to rubber in the Congo took place', Casement was quick to protest: 'No ... - in consequence really of the public feeling raised 
by public reports outside, ${ }^{53}$

Despite its lobbying, the British government failed to get other states to join an international convention on the Berlin Act and would contemplate no autonomous action. Gunboat diplomacy - blockading the mouth of the Congo until reforms were effected - would be nothing less than 'an act of war'. ${ }^{54}$ Instead, the British government hoped to persuade the Belgian government to take over the royal demesne. In 1906, the British government, now with a more aggressive foreign secretary, confronted the Belgian king with the CRA evidence, but Leopold II insisted that his rights in the Congo were 'personal and indivisible' and that no other 'Power has the right of intervention'. ${ }^{55}$ When, finally, in 1908, the Belgian government took control of the Congo away from the king, this was a significant victory for Casement and the CRA. Annexation had 'placed the whole of the system of administration of the Congo under the searchlight of Parliamentary criticism, ${ }^{56}$ In turn, then, the Belgian parliament would be shoved by continual international pressure to make colonial policy 'answerable to the Belgian national conscience'.$^{57}$

Having described how criticisms of colonial practice were developed within the executive and articulated in parliament, we now want to establish the specifically anticolonial character of Casement's testimony on the Congo. The coherence of his critique is impressive and it is striking that he tried to find both within colonial administration itself and British liberalism more broadly the principles upon which to base it. From colonial administration, he drew an array of rights possessed by colonial subjects and from British liberalism he developed an extensive set of obligations to prevent injustice and injury. These led him to the conclusion that there could be no principled colonialism since it rested upon the sins of dispossession and the brutal extraction of primary exports. After this, his route to Irish rebellion was direct and it gave him his final platform - his judicial moment - from which to speak about these solidarities. 


\section{SUBJECT RIGHTS AND HUMAN RIGHTS}

In claiming colonies, the British made subjects of the inhabitants and as those people crossed borders they took this status with them. Across the world, British consuls had a responsibility to look after the rights and interests of British subjects and although the realm of the consul had once been largely commercial by the later nineteenth century it increasingly encompassed welfare and intelligence matters. ${ }^{58}$ In the Congo, Africans who were British subjects were employed in the armed forces that were used to force natives to 'mortally' slash the rubber trees, while other British subjects were employed as labourers building infrastructure for the rubber business, plying trade in rubber and serving as missionaries. ${ }^{59}$ This gave Casement plenty of scope in his reports to the civil servants in the Foreign Office. At one point he reported that one British subject from West Africa, in the Congo on a two-year labour contract, had been bludgeoned to death by a European overseer. ${ }^{60}$ With its responsibilities outside Britain's formal empire, the consular service was drawn into adjudicating the justice of other colonialisms and, implicitly via the accumulation of parallels, of colonialism in general.

With and sometimes without an interpreter Casement resolved to work by negotiation rather than force in his dealings with African people. Recalling his own time with Casement on the Congo coast, Joseph Conrad wrote: 'He knows the coast languages well. I went with him several times on short expeditions to hold "palavers" with neighbouring village-chiefs". ${ }^{11}$ But indigenous testimony was not readily accepted in London and was dismissed by one civil servant as no more than 'vague rumours and hearsay reports'. ${ }^{62}$ Casement also noted local understanding of European prejudice: '[W]e begged the white man to leave us alone, saying we could get no more rubber, but the white men and their soldiers said: "Go! You are only beasts yourselves, you are nyama (meat)"'. ${ }^{33}$ The Congo government was quick to dismiss his report as an 'easy accumulation not of facts, simple, precise, and verified, but of the declarations and affirmations of natives'. ${ }^{64}$ But even a commission sent out by Leopold II had eventually to accept local claims 
when a missionary, John Harris, 'brought canoe load after canoe load of witnesses'. ${ }^{65}$

Casement believed his local informants from the start and he wanted both to get them justice and to end the system under which they suffered, and in this he was not limited by the reach of British subjecthood. When he learned of Germans hiring Dahomeans who were later accused of killing natives in the German colony of Cameroon, he insisted that the local British consul write in protest to the German government for 'we all on earth have a commission and a right to defend the weak against the strong. ${ }^{66}$ Writing in 1911 about this broader conception of human rights he told Alice Stopford Green, an Irish nationalist and historian that he had befriended during their work together for the CRA, 'If we free the Congo slave we smite the Mexican slaver - international humanity is the only check to international financial greed'. ${ }^{67}$ However, this comprehensive notion of international human rights was not something that the British government accepted. In its communications with the Congo and Belgian governments, the British government distanced itself from the CRA and from the heat of public opinion. In 1909, after annexation, the foreign secretary told the Belgians that 'the British Government was not responsible for anything said by the Congo Reform Association'. ${ }^{68}$ Yet, the arrangement described by Casement was easily described as slavery and this made it a matter of human rights and not just treaty rights since the British government had committed itself to the global elimination of the slave trade in $1807 .{ }^{69}$ In this spirit, the archbishop of Canterbury told the House of Lords that it was 'unquestionably true that negro slavery has been resuscitated ... in the Congo', and thus they were 'face to face with the big principles of right and wrong. ${ }^{70}$

Casement actually made very little reference to slavery in his own report. He gave the regime of Leopold II credit for expelling Arab slave traders from the region, commenting that 'the suppression of an open form of slave dealing has been an undoubted gain', but he also noted that the army quashing this trade was recruited in a manner 'little removed from the malpractices that service was designed to suppress'. ${ }^{71}$ Yet the terms of the Berlin Act gave 
Casement an opening for a broader review that explicitly brought colonialism itself into question. By Article VI of Chapter I of the Berlin Act, 'the Powers bound themselves to watch over the preservation of the native tribes, and to care for the improvement of the conditions of their moral and material well-being. ${ }^{72}$

Casement noted that a regime that could only get rubber by force was rotten to its core. Though many Europeans believed that Africans were lazy and had to learn the moral benefits of hard work, Casement took this argument and stood it on its head: 'If the labour be unhealthy, demoralizing and only possible in a compromising environment the character of the labourer and therefore of the nation to which he belongs is deteriorated' ${ }^{73}$ Here it was the nature of the work, not the native, that produces cowed and demoralized subjects. Moreover, in the Congo, as Casement was aware, the Belgian crown appropriated all land that it decided was not under individual occupation, and then declared that the local people owed a labour duty as a tax towards the costs of administering the occupation and expropriation. Casement questioned both the right of the Congo government and the capacity of local chiefs to consent to such an arrangement.

One civil servant, Harry Farnall, sounded an alarm, suggesting that it would be 'out of the question to limit the powers of a civilised government to those of the native chiefs', because the 'British crown claims the right to dispose of vacant land both in colonies and in Protectorates'. The foreign secretary himself recognized Casement's argument as 'valuable and interesting', even if it 'proves too much' ${ }^{74}$ But the British government retained quite a bit of Casement's argument in its own commentary upon the injustice of the Domaine de la Couronne:

His Majesty's Government in no way deny either that the State has the right to partition the State lands among bona fide occupants, or that the natives will, as the land is so divided out among bona fide occupiers, lose their right of roaming over it and collecting the natural fruits which it produces. But; 
His Majesty's Government maintain that until unoccupied land is reduced into individual occupation, and so long as the produce can only be collected by the native, the native should be free to dispose of that produce as he pleases. $^{75}$

This imagines a transition from collective, native occupation to owner-occupier farmers such as happened in very few colonies, but it is clear that Casement's argument was heard as an attack on colonialism tout court. Castigating individual evil-doers might have allowed the force of the criticism to be contained, whereas, focusing upon a system invited strategic comparisons and judicious appraisal. For example, in explaining to Dilke the government's hesitation to push vigorously for a meeting of all the signatories to the Berlin Act, Lansdowne, as Foreign Secretary, worried that it might reopen the whole geopolitical arrangement in Central Africa, 'which would not be in our interest'. France was reluctant to join such a conference for fear of drawing attention to its own colonial practices in its Congo territories. ${ }^{76}$ In one minute of 1905 , Lansdowne conceded that the Congo regime was ' $\mathrm{g}]$ hastly but I am afraid the Belgians will get hold of the stories as to the way the natives have apparently been treated by men of our race in Australia'. ${ }^{77}$ In this respect, then, the humanitarian claims of the Berlin Act created space for a civil servant to elaborate his own commentary upon colonialism, an attack that, as we demonstrate below, drew upon his understanding of British colonialism in Ireland but developed it as a systematic, even theoretical, argument. ${ }^{78}$

In 1911, looking back on the Congo from his later work against a similar regime in Putumayo, Casement concluded that 'the same game of land confiscation [was] the key in both cases'. In a contemporaneous letter he put the matter more forcefully: 'The expropriation of the Indians, and bare-faced denial of all rights in land to the Indians is at the bottom of the whole system of slavery that undoubtedly exists in those [Amazonian] regions'. He made the same point to the Foreign Office, blaming Europeans who took 'no account whatsoever of ... pre- 
existent native rights and long-established methods of existence'. In this case, the British government had a duty to ensure good conduct because the Peruvian Amazon Company (PAC) was registered on the London stock exchange and Casement insisted that it had to be reconstituted top to bottom 'to do away with exploitation' and respect 'the innate and individual rights of the Indians'. ${ }^{79}$

During the Congo agitation Casement wrote to the philanthropist who had largely funded the campaign: ' $[1] \mathrm{t}$ was only because I was an Irishman that I could understand fully, I think, the whole scheme of wrongdoing at work on the Congo'. ${ }^{80}$ The 'whole scheme', then, was founded on expropriation and coercion. Casement certainly appreciated that this analysis of the Congo question was controversial within the British Foreign Office. As he wrote to Alice Stopford Green, an Irish nationalist friend, in 1907: 'I knew the FO would not understand the thing ... for, I realised that I was looking at this tragedy with the eyes of another race - of a people once hunted themselves' ${ }^{81}$ Although, as he explained to her, living in Africa during the 1890s he had broadly accepted that European colonialism was a progressive and civilizing force, his views had changed with what he saw of the conduct of the Boer War and particularly of the concentration camps set up at its close, and, after that, in 'those lonely Congo forests where I found Leopold I found also myself - the incorrigible Irishman'. ${ }^{82}$ He had also used these terms in 1905 when he wrote to an Irish MP whom he wished to recruit to the Congo cause: 'In the light of our past history and of all that the native Irish suffered at the hands of exploiters and exterminators we should be the last people on earth to take part, today, with those who are playing the same old game'. ${ }^{83}$ In another letter, Casement referred to the Irish as 'the white slave race of European peoples' ${ }^{84}$ The notion that Ireland might be underdeveloped in a manner that recalled the least civilized parts of the world was not unusual, as David Nally shows in his work on the Great Irish Famine, but it was less common to present this as an indictment of British administration rather than blame native failings. ${ }^{85}$ Furthermore, during the public debate sparked by his report on the savage exploitation of indigenous people by the PAC, Casement drew an explicit comparison 
between poor administration in Peru and in Ireland, writing a letter to the Irish Independent about an outbreak of typhus fever at Lettermullen, County Galway, that called the district an Irish Putumayo and lamented the 'absence of anything like civilised government in that part of the world'. Despite subsequent criticism for having exaggerated the public health crisis in the west of Ireland, Casement told Green that he thought the comparison had done nothing but good for 'widespread public attention has been called to the evil and wicked plight of those poor people a remnant of Cromwellian civilisation sitting in the embers of the hell of Connacht then decreed the doomed Irish race'. ${ }^{86}$

The Irish dimension of Casement's thought is important, and existing studies treat it in diverse ways. Bernard Porter, for example, suggests that Casement's analysis of colonialism was a product of his Irish background, where he had learned to hold landlordism accountable for a range of socio-economic evils. ${ }^{87}$ Casement's Irish nationalism was certainly quickened by the example of his fellow Protestant, Charles Parnell, who dominated the 1880s, leading a nationalist movement that began as an attack upon landlordism and ended as a campaign for Home Rule. Honouring the day of Parnell's death in 1891, Casement wrote a poem that anticipated the realisation of Parnell's hopes: 'Through and beyond the breach he living made | Shall Erin pass to freedom' ${ }^{88}$ Writing of Alice Stopford Green, who, as an historian, wielded significant intellectual and political influence over Casement, Pavlakis is sure that 'her reflexive antiimperialism sprang from her sympathy for the plight of her native Ireland' ${ }^{89}$ This suggests that it was a matter of the heart and not the mind, yet Green developed her ideas through empirical research and in this way she educated Casement about their country too. In The Making of Ireland and its Undoing, 1200-1600 (1908), she documented long-standing differences between English and Irish society, 'demonstrating the cultural basis for an independent Irish state'. In Irish Nationality (1911), she went even further back to argue that whereas England followed the example of the Roman Empire and developed a centralised state with a 'sovereign ... supreme in the domain of force and maintenance of order', the tribal basis of Irish society allowed 'self- 
governing communities, ... bound together in a willing confederation'. Casement followed her work carefully, praising her 'magnificent mind' after reading The Making of Ireland and its Undoing, and, in 1911, he was so impressed with Irish Nationality that he floated a scheme to have it 'sold by hand throughout Ireland'. ${ }^{90}$ In important ways, then, Casement's nationalism developed from his anticolonial activism.

However, Andrew Porter is convinced that Casement is the very opposite of a coherent anticolonial thinker, developing no 'mature reflections on the general issues involved'. ${ }^{91}$ Porter correctly suggests that Casement offered multiple suggestions for improvements in different contexts_-sometimes a Catholic missionary effort, sometimes a reformed trading company, and sometimes a switch from US to German colonisers - and he is also prescient in relating this to Casement's pragmatism. But this does not mean that Casement did not see a similar set of causes manifesting as multiple evils in each of these contexts. Extortion following land expropriation is the consistent theme, and it was fed by his knowledge of Irish history. Porter concedes that the 'humanitarian strand in British nationalism' was 'often unsympathetic ... to the nationalisms of others'. ${ }^{92}$ In this regard, the nationalism of the Irish was a particular blind-spot since it rested so clearly upon identifying the colonialism of their British neighbours. Richard Kirkland believes that this is why Casement poses a particular problem for British opinion: 'his disavowal of Britain disturbs a perception of the British State as self-reforming in its capacity to analyse and ultimately discard its adherence to the colonial project through enlightened administration'. ${ }^{93}$

As Europe slid towards war, Casement blamed British imperialism for the roiling tumult. He argued that by controlling the world's seas, the British were able to limit the access to world markets of their European rivals. Casement said that Britain wanted 'a Europe divided against itself so that England, untroubled by competition, unchecked by challenge, might appropriate the market of mankind'. He argued that British control of Ireland was critical to Britain's maritime supremacy and thus Germany had a clear interest in Irish independence: 'The German 
gateway to a free Atlantic can only be kept open through a free Ireland'. ${ }^{94}$ As the First World War intensified, and at a point when he was in Germany and a British blockade prevented him sending cables to co-conspirators in Ireland or the United States, Casement expostulated about Britain in the privacy of his diary: 'This is a fine measure of freedom of communication! My God! How much more will the world have to stand from that Bitch and Harlot of the North Sea! ${ }^{95}$ This brought Casement to his final anticolonial challenge and ended with him expressing his mature thought from the dock of a British court.

\section{SPEAKING FROM THE DOCK}

In November 1913, Casement was involved in founding the Irish Volunteers (IV), a political movement and militia committed to defending Irish Home Rule. Home Rule had been promised by a bill introduced to the House of Commons in 1912, which was then rejected repeatedly in the House of Lords, and also threatened by the Ulster Volunteers (UV), a militia established to oppose its implementation. Home Rule for Ireland was finally enshrined in an act of parliament in September 1914, but was immediately suspended for the duration of the war with Germany. In May 1914, Casement was part of a small group deciding that the IV should buy guns in Germany and bring them back into Ireland, which, in defiance of a British ban on the importing of guns to Ireland, was achieved on 26 July 1914. Casement had already left Ireland to raise funds in North America and the news of the successful gun-running helped him enormously. On 2 August 1914 Britain declared war against Germany. In Washington DC Casement met the German ambassador to the United States and asked that Germany make as statement supporting Irish independence. ${ }^{96}$ By November 1914 Casement was in Germany trying to secure this statement, seeking German arms for the Irish revolution, recruiting Irish prisoners of war for an Irish Brigade, and asking that displacing British power in Ireland be part of the German war plans. He got the statement he wanted but, beyond that, very little German logistical or military support. 
The Germans wanted a rebellion in Ireland because it would distract British troops, and because its suppression might alienate Irish-American opinion and thereby prevent the United States entering the war (the US did not enter the war until April 1917). Neither of these goals required that the Irish rebels actually succeed and the German government committed no officers or men to the venture. Nevertheless, with two compatriots Roger Casement was landed from a submarine onto Banna Strand near Tralee on Good Friday, 21 April 1916. The ship bringing arms was not met by the anticipated group of local rebels and after a brief pursuit its crew scuttled the boat sending the arms to deep oblivion. Casement had few illusions about the likely success of the rebellion, sharing with his diary the belief that it was 'the maddest and most ill planned enterprise in the history of Irish revolutionary efforts'. ${ }^{97}$ He was arrested near the beach and, following a night in police custody in Tralee, he was taken to London. He was interrogated and then brought to trial and so began a further episode of publicity, the public exercise of justice: the third, and judicial, moment of government.

Initially, Casement was kept at the Tower of London until authorities decided upon a civil rather than a military trial, when he was moved to Brixton prison. ${ }^{98}$ A civil trial gave the maximum publicity and aimed to allow justice to be seen to have been done. However, it also gave the accused an opportunity to defend themselves. Many speeches from the dock have been celebrated and affective as expressions of Irish nationalism and defiance. Perhaps the most famous of these was Robert Emmet's, after sentence of death was passed for his part in the rebellion of 1803 and specifically for the treasonous act of having sought French assistance in liberating Ireland. He said that the British judges were quite unable to understand his motives but instead he addressed a future when in a free Ireland people might openly avow the principles for which he now surrendered his life: 'Let no man write my epitaph: for as no man who knows my motives dare now vindicate them, let not prejudice or ignorance asperse them'. ${ }^{99}$ In all sorts of ways, Casement modeled himself on Emmet, a fellow Protestant seeking foreign assistance in the struggle to expel tyranny from Ireland. ${ }^{100}$ It is striking that the German authorities gave a 
copy of Emmet's speech to Casement in April 1916, preparing him perhaps for the fate they anticipated. ${ }^{101}$

A state trial for treason is a complex matter and Casement had neither the stamina nor legal training to conduct his own defence. Unfortunately, no leading British barrister would act for him either and when the Irish barrister George Gavan Duffy offered to help Casement his partners in his London law firm threatened to dissolve their enterprise, which they subsequently did. ${ }^{102}$ A relatively junior Irish lawyer, Alexander Sullivan, agreed to lead the defence. Casement faced not only a court in a country at war, but also some of the more extreme Unionists of the day. His interrogation had been led in part by Major Frank Hall who had been organising gunrunning for the UV until he joined MI5 at the start of the war. ${ }^{103}$ In court, he faced the attorney general, Frederick (F.E.) Smith, so hostile to Irish nationalism that he not only visited Ireland to inspect the militia of the UV, but in a speech of 12 July 1912 went so far as to suggest that resisting Home Rule was 'one of those supreme issues of conscience amid which the ordinary landmarks of permissible resistance to technical laws are submerged'. ${ }^{104}$ The lead prosecutor as lord chief justice was George Cave, another Unionist Conservative. Between them Smith and Cave tried to limit the frame of reference within which the case for Casement could be made.

When Sullivan tried to establish that the Irish Volunteers might have been arming in response to the earlier determination of the UV to arm themselves and to defy by force the introduction of Home Rule, even though that be the law, Cave interrupted with 'Have we not gone far enough into this?' to which Sullivan replied meekly 'Very well, my lord, I at once accept the suggestion'. And when Cave referred again to arms imported by Unionists, Smith himself intervened to insist that these were statements 'wholly uncorroborated' and both Cave and Sullivan supported the intervention. By restricting Sullivan early in the trial, Smith and Cave limited what he could use in his summing up since many of the points he wanted to make had not previously been entered in evidence. The badgering of Sullivan left him in pieces and he 
retired, saying that he was 'completely broken down'. When Artemus Jones, as substitute for Sullivan, was given like treatment he allowed himself this mild sarcasm: 'One eminent judge once observed that a thing most notorious outside a Court of law was the thing most difficult to prove inside a Court of law'. The entity that was conjured away during the trial was the thing most dear to Casement: Irish nationality. Smith and Cave insisted that the trial was about treason in time of war. It was a matter between Britain and Germany and what had to be decided was whether Casement, by embarrassing or distracting Britain in time of war, 'a weakening of the forces of the King', were not aiding Germany in a zero-sum game. ${ }^{105}$

Casement's sexual relations with other men were known to the British government. He told his legal team that should his character be brought into question 'I must bear it - and carry the war into their camp by saying "alright - you knew all that long ago, yet you suggested my return to your service on 26 October 1914"'. ${ }^{106}$ But all involved knew that it would reduce sympathy for him were it made public and avoiding cross-examination that might have alluded to his sexuality is likely one reason why Casement was not called in his own defence. Sexually explicit entries from one of Casement's diaries - discovered at his digs in London - were photographed and circulated widely. Newspaper articles began to drop hints and prominent allies privately abandoned him. Indeed, the notion that a diary might be relevant to the case was trailed by an exchange of almost music hall banter between Smith and Cave as each insisted that they were not introducing a diary explicitly into the trial since they could not be sure it was Casement's. While the diary they were alluding to was just a document that listed Casement's movements in Germany, the way Smith and Cave noted that there was a 'diary which was found, and is in evidence as having been found', offered sufficient ambiguity to suggest that the compromising diary was also in evidence. ${ }^{107}$ As Ernly Blackwell advised the British cabinet when it was debating commuting the capital penalty: 'His private character is by this time pretty generally known in London. The Daily Express on three occasions has openly stated he is a moral degenerate, addicted to unmentionable offences, and has cited his "diaries" in proof. ${ }^{108}$ 
George Bernard Shaw told the Casement team that their only hope was to produce a defence that might at least divide the jury, and that confusion might be fomented by appealing as an Irishman to themselves as Englishmen:

I advised Casement to conduct his own defence; to plead not guilty but admit all the facts; to assert his complete right to act as he had done; to claim that as he was a prisoner of war and not a traitor his execution would be a murder; to be eloquent about his right to take up arms for the independence of his country; and to finish with a defiant 'Now murder me if you like and be damned.' ${ }^{109}$

There was some faint echo of this in Sullivan's intercession when he asserted that: 'The prisoner is not a countryman of yours.... He comes from another country where people, though they use the same words, perhaps, speak differently; they think differently; they act differently'. ${ }^{110}$ But this was even less nationalist than Shaw's proposal. Casement's own speech, which he gave only after sentence was passed, was not only nationalist, like Shaw's proposal, but also militantly anticolonial.

Casement stressed that nationalism was a matter of conscience, and that it was barbaric to punish people for their beliefs. Modern government should be based on something better, on loyalty freely given, on rights fully recognised. Casement's central argument was about the difference between restraint and loyalty: 'Loyalty is a sentiment, not a law. It rests on love, not on restraint. The Government of Ireland by England rests on restraint and not on law; and since it demands no love it can evoke no loyalty'. Casement professed that English liberty rested upon trial by one's peers: 'With all respect I assert this Court is to me, an Irishman, not a jury of my peers'. Casement noted that the Crown's case effectively erased Ireland and Irish identity: '[F]or the Attorney-General of England there is only "England" - there is no Ireland, there is only the law of England - no right of Ireland; the liberty of Ireland and of Irishmen is to be judged by the 
power of England'. The fact that the English would not trust a jury of Irish people to convict Casement was proof of the illegitimacy of their claim to rule:

That, my lord, is the condemnation of English rule, of English-made law, of English Government in Ireland, that it dare not rest on the will of the Irish people, but it exists in defiance of their will - that it is a rule derived not from right, but from conquest. Conquest, my lord, gives no title, and if it exists over the body, it fails over the mind. It can exert no empire over men's reason and judgment and affections.

In the context of a war to defend the British Empire, Casement had a different allegiance: That blessed word 'Empire' that bears so paradoxical resemblance to charity! For if charity begins at home, 'Empire' begins in other men's homes, and both may cover a multitude of sins. I for one was determined that Ireland was much more to me than 'Empire', and that if charity begins at home so must loyalty. ${ }^{111}$

So, on one side there was force, conquest and empire, and on the other there was love, loyalty, charity and rights. The analysis of coercion that was central to Casement's understanding of colonialism was now at the heart of his final argument about the illegitimate claims of colonialism upon his own body:

Where all your rights become only an accumulated wrong; where men must beg with bated breath for leave to subsist in their own land, to think their own thoughts, to sing their own songs, to garner the fruits of their own labours ... then surely it is braver, a saner and a truer thing, to be a rebel in act and deed against such circumstances as these than merely to accept it as the natural lot of men. ${ }^{112}$

As a rebel, he was subject to the fatal force of the judicial might of an imperial power, but to 
justify his judicial killing Casement had been given a public trial and he took this last opportunity to describe the violence, expropriation and illicit character of colonialism, in this case that wrought on his own Ireland.

\section{ANTICOLONIALISM AT THE HEART OF EMPIRE}

Anticolonial sentiments were both incited and repressed at the heart of empire. The consular service, as part of the executive moment of governance, took place in non-British territories but, in serving British subjects living under the rule of other colonial authorities, British consuls might find themselves criticizing the nature of that colonial rule. ${ }^{113}$ Those criticisms would be debated within the civil service back in London and used to inform ministerial statements to parliament. In this manner, Casement took up the question of British subjects working as little better than indentured servants as part of the rubber extraction enterprises in both the Congo and Putumayo. He also found British-registered companies within his bailiwick and held them to account for their labour practices. Casement saw consular work as very like diplomacy for, while 'consuls were originally intended to ... represent a commercial community', they now acted on behalf of 'Government, and his official duties take up practically all his time'. ${ }^{114}$ In that diplomatic capacity, Casement took an interest in the obligations implicit in anti-slavery treaties, including the diplomacy around the Berlin Act. To some extent this was no more than the ethical or 'alchemical' humanitarianism, of his contemporaries. ${ }^{115}$ However, it is important to recognize that this was not the limit of Casement's view. His anticolonialism separated him from these varieties of humanitarianism.

There are several studies that trace the ways that networks of humanitarianism developed alongside colonialism and in the main they find a Christian philanthropy that invested empire with a civilising mission. ${ }^{116}$ This was precisely what Casement gave up after his experience during the Boer War. He returned to the world-view that had animated his earlier support for the Land War against landlordism in Ireland. ${ }^{117}$ For Casement, land expropriation left indigenous labour 
vulnerable to extortive practices. This had happened in Ireland and it was happening in Congo and Putumayo. His minders in the Foreign Office were well aware of the reach of such an analysis and sought various formulations that would limit its applicability only to the colonialism of others. Yet, both Casement's reports on rubber indicted a system and not just a few miscreants.

The critical material produced within the executive was ultimately recirculated within the debating chambers of the legislature, because the legitimation of action by branches of the executive such as the Foreign Office, requires that it be seen to be willing to submit to parliamentary and thus public scrutiny. However, the executive can censor reports and delay their publication. When Casement briefed journalists in advance of the release of his report on the Congo, he was rebuked by the Foreign Office. Yet he wrote at least one anonymous article for the press during the Putumayo campaign, reassuring the editor of the Daily News that it was safe from any prosecution for libel, and he continually pressured the Foreign Office to publish his Putumayo report arguing that reform would only be brought by publicity and the 'compulsion of civilised communities'. ${ }^{118}$ During both campaigns Casement was in London for much of the time and spoke privately with activists and members of parliament. In this nexus of press and parliament the anticolonial message was squeezed at both ends. The public campaign was primarily tied to the Christian philanthropy that Alan Lester, Ian Tyrrell and others have described. ${ }^{119}$ The missionaries were not keen to be public critics of a state that could exclude them from their missionary field. In parliament the government of the day was always chary of rebuking a European ally and equally wary of allowing any broad criticism of colonialism for fear that it might expose British practices to comparable slight. Both these consequences did follow and while the references to colonial rule in Ireland were in a minor voice, the colonial character of the Congo and of Putumayo was established in ways that invited precisely the more general castigation of empire that Casement advanced. 
Parliament, however, was largely deaf to this appeal and, outside the cabal of Irish nationalist MPs, was particularly unlikely to accept an anticolonial case in favour of Irish independence. Supporting Casement's Congo campaign, Dilke, although a radical Liberal, did believe in the possibility of a benign empire, even for Ireland. Curzon, on the other hand, opposing the Congo reforms, was an imperialist of the purest water who went to India as viceroy at the start of 1899. He was also vehemently opposed to Home Rule for Ireland and, in 1886, had made his opposition the subject of a maiden speech in the House of Commons. ${ }^{120}$ As noted previously, F.E. Smith was trenchant in resisting Irish Home Rule in 1916, but he was also the most extreme of imperialists in general terms, viewing colonial rule as a progressive and evolutionary principle in human history: 'nations of stronger fibre, confronted by indigenous weaklings, have always asserted the right of forcible expropriation. No one ... who has studied the history of the world has ever defended the view that the supreme interest of evolutionary humanity can support a definitive delimitation for all time of the surface of the world'. ${ }^{121}$ In generalizing an anticolonial message from his reports, and particularly in extending it to the Irish case, Casement faced serious obstacles in his interactions with both the executive and legislative moments of governance.

Even within Irish nationalism, Casement's anticolonial voice was far from universal. Indeed, as he was told by William Scawen Blunt, the constitutional nationalist John Redmond considered Casement 'a dangerous revolutionist, being anti-imperialist'. ${ }^{122}$ Of course, Redmond was right and Casement came to make common cause with the rebels in the Irish Republican Brotherhood, a clandestine revolutionary group that infiltrated the leadership council of the Irish Volunteers. Casement brought himself to the point in the First World War where he sought assistance from Britain's enemy, Germany, and landed himself in court on a charge of high treason. At this point his anticolonial message echoed through the third, the judicial, moment of governance. Following a charge of treason rather than rebellion, Casement got a public trial in London, rather than a secret court-martial in Ireland. It was not military justice but, rather, civil 
justice that arraigned Roger Casement. Once again, the organs of government engaged publicity and, despite the asymmetry of relations, the Irish man had to be heard. In one final performance, one of those 'weapons of the weak', Casement brought colonialism's violence into public view. ${ }^{123}$ His argument was that British rule in Ireland rested upon coercion not consent, and the evident partisanship of his accusers plus the raucous hostility of the general public in London support his claim. As he was led from his cell to the scaffold a baying mob outside the prison assailed him, causing at least one newspaper to question the much-vaunted British civilisation: 'The cheers of that London mob, on that beautiful August morning when all creation was joyous with the joy of living will re-echo from every civilised nation in the world a wail of horror and disgust. It is one of those terrible blots which will stain with an indelible stain the fame of the great British Empire for ever'. ${ }^{124}$ Yet Casement's argument that the social order must be based on love to command loyalty was not lost on all who read his final speech. In his cosmopolitan reading of sexuality and nationality, James Joyce gave to his favourite character, Leopold Bloom, a speech very like Casement's when, under attack from nationalist bigots, Bloom responds:

- But it's no use, says he. Force, hatred, history, all that. That's not life for men and women, insult and hatred. And everybody knows that it's the very opposite of that that is really life.

- What? says Alf.

- Love, says Bloom. ${ }^{125}$

\footnotetext{
${ }^{1}$ B. Porter, Critics of Empire: British Radicals and the Imperial Challenge, London, 1968; G. Claeys, Imperial Sceptics: British Critics of Empire, 1850-1920, Cambridge, 2010. The parliamentary debates provoked by dissent in the North American colonies in the years preceding the American Revolution cast a cold eye over colonialism: I. R. Christie, The Earl of Chatham and American taxation, 1774-1775, Eighteenth Century 20 (1979) 246259. In parliament Edmund Burke attacked British administration in India: L. Gibbons, Edmund Burke and Ireland: Aesthetics, Politics and the Colonial Sublime, Cambridge, 2003. Anticolonial arguments were incited by various inquiries: E. Elbourne, The sin of the settler: the 1835-36 Select Committee on Aborigines and debates over virtue and conquest in the early nineteenth-century British white settler Empire, Journal of Colonialism
} 
and Colonial History 4 (2003) 1-46.

${ }^{2}$ C. Nash, Cultural geography: postcolonial cultural geographies, Progress in Human Geography 26 (2001) 221; A. Lester, Imperial Networks: Creating Identities in Nineteenth-Century South Africa and Britain, London, 2001; A. Lester and F. Dussart, Colonization and the Origins of Humanitarian Governance: Protecting Aborigines across the Nineteenth-Century British Empire, Cambridge, 2015.

${ }^{3}$ For Casement's early life: J. Dudgeon (Ed.), Roger Casement. The Black Diaries, with a Study of his Background, Sexuality and Irish Political Life, second edition, Belfast, 2016 [2002].

${ }^{4}$ For his official career: S. Ó Síocháin, Roger Casement: Imperialist, Rebel, Revolutionary, Dublin, 2008, ebook.

${ }^{5}$ For his Irish nationalism: B. Inglis, Roger Casement, London, 1973.

${ }^{6}$ A. Hochschild, King Leopold's Ghost: A Story of Greed, Terror, and Heroism in Colonial Africa, Boston, 1998.

${ }^{7}$ E.D. Morel, King Leopold's Rule in Africa, London, 1904, chapter III. The extent of the Domaine de la Couronne and of the Concessions are based on: S.J.S. Cookey, Britain and the Congo Question 1885-1913, London, 1968, xvi; N. Ascherson, The King Incorporated: Leopold the Second in the Age of Trusts, London, 1963, 192.

${ }^{8}$ R.E. Mitcham, Geographies of global humanitarianism: the Anti-Slavery Society and the Aborigines Protection Society, 1884-1933, unpublished PhD thesis, Royal Holloway, University of London, 2001.

${ }^{9}$ Hansard, House of Commons [HC] Debates [Deb.] 48 (2 April 1897) c. 426; c. 428.

${ }^{10} \mathrm{P}$. Corcoran, John Locke on native right, colonial possession, and the concept of vacuum domicilium, European Legacy 23:3 (2017) 225-250; J. Whitehead, John Locke, accumulation by dispossession and the governance of colonial India, Journal of Contemporary Asia 42:1 (2012) 2-21; Cookey, Britain and the Congo Question, 8.

${ }^{11}$ D. Pavlakis, British Humanitarianism and the Congo Reform Movement, 1896-1913, New York, 2016 [2015], 242.

${ }^{12} \mathrm{HC}, 2$ April 1897, c. 434.

${ }^{13}$ Ó Síocháin, Roger Casement, 236.

${ }^{14}$ HC Deb. 79 (27 February 1900) c. 1215; HC Deb. 67 (27 February 1899) c. 729; HC Deb. 87 (6 August 1900) c. 775; E.S. Grogan, Through Africa from the Cape to Cairo, Geographical Journal 16 (August 1900) 178.

${ }^{15}$ HC, 6 August 1900, c. 776.

${ }^{16}$ Ó Síocháin, Roger Casement, 328, 330.

${ }^{17}$ HC Deb. 119 (15 November 1906) c. 382; HC 121 (4 May 1903) c. 1196.

${ }^{18}$ HC 122 (20 May 1903) c. 1294, c. 1332, c.1320, c. 1331.

${ }^{19}$ HC Deb. 165 (21 November 1906) cc. 96-7.

${ }^{20}$ Ó Síocháin, Roger Casement, 352.

${ }^{21}$ Casement to Edmund Morel, 29 June 1909, quoted in Ó Síocháin, Roger Casement, 446. An interpretation endorsed in Pavlakis, British Humanitarianism, 255.

${ }^{22}$ The dates of Casement's journey are taken from: R. Casement, The 1903 diary, in S. Ó Síocháin and M. O' Sullivan (Eds), The Eyes of Another Race: Roger Casement's Congo Report and the 1903 Diary, Dublin, 2013, 185-308.

${ }^{23}$ R.M. Burroughs, Travel Writing and Atrocities: Eyewitness Accounts of Colonialism in the Congo, Angola, and the Putumayo, London, 2011, 72. Casement describes spending 21-22 July in Mpoko with Scrivener, interviewing people who had fled south from the vicinity of Lake Leopold II, well within the Domaine de la Couronne: R. Casement, Notes on refugee tribes encountered in July 1903, in Ó Síocháin and O' Sullivan, Eyes of Another Race, 118127. The version published as a parliamentary paper lacked these personal and place 
identifiers.

${ }^{24}$ In his diary for 1903, Casement listed three books about the Congo for purchase, presumably to bring with him on his trip. One was: E.D. Morel, Affairs of West Africa, London, 1902. Morel analysed the export statistics of the Congo Free State (pp. 343-353) and, in treating rubber and ivory brought to market by the Belgian Crown as its index, showed that the bulk of rubber came to market as a product of direct taxation, rather than commercial exchange. Morel did remark upon the quantity of guns traded for ivory (p. 351) but did not remark, as Casement did, upon the paucity of imports (trade goods) introduced into the Upper Congo as imports to balance the rubber exports. In 1904, after Casement's Report, Morel produced a further book, in which he did give figures on the balance of trade of the Congo Free State, including estimates of trade goods, showing a ratio of 4:1 in favour of exports; significantly less than the ratio calculated by Casement but still indicative of intense exploitation: Morel, King Leopold's Rule, 55-6.

${ }^{25}$ Casement to Foreign Secretary, 11 December 1903 [Congo Report], in British Parliamentary Papers [BPP] 1904 Cd. 1933, lxii, 357, Africa. No. 1 (1904). Correspondence and Report from His Majesty's Consul at Boma Respecting the Administration of the Independent State of the Congo, 21.

${ }^{26}$ Ó Síocháin, Roger Casement, 94-5.

${ }^{27}$ S. Ó Síocháin, General introduction, in Ó Síocháin and O’ Sullivan, Eyes of Another Race, 39.

${ }^{28}$ Inglis, Casement, 86, 89.

${ }^{29}$ Congo Report, 26.

${ }^{30}$ W.R. Louis, Roger Casement and the Congo, Journal of African History 5 (1964) 107.

${ }^{31}$ BPP 1904 Cd. 1809, lxii, 517, Africa. No. 14 (1903). Despatch to Certain of His Majesty's

Representatives Abroad in Regard to Alleged Cases of Ill-Treatment of Natives and to the Existence of Trade Monopolies in the Independent State of the Congo, 1.

${ }^{32}$ Note from the Congo government to the representatives at Brussels of the Powers parties to the Act of Berlin, in Africa. No. 1 (1904) 9.

${ }^{33}$ HL Deb. 179 (29 July 1907) c. 432.

${ }^{34}$ Congo Report, 49.

${ }^{35}$ Congo Report, 43. Casement, The Congo report, in Ó Síocháin and O’ Sullivan, Eyes of Another Race, 88. In their edition of the report, Ó Síocháin and O' Sullivan have restored the names and places suppressed when first it was published, and also reinstated passages deleted from Casements drafts.

${ }^{36}$ Congo Report, 43.

${ }^{37}$ Congo Report, 61.

${ }^{38}$ Congo Report, 46, 45, 82, 59.

${ }^{39}$ Quoted in: Notes prepared by Congo government as a preliminary reply to $\mathrm{Mr}$. Casement's Report, in BPP 1904 Cd. 2097, lxii, 445, Africa No. 7 (1904). Further Correspondence Respecting the Administration of the Independent State of the Congo, 15.

${ }^{40}$ England and the Congo State, Times (15 February 1904) 6.

${ }^{41}$ Africa No. 1 (1905), 27; Africa No. 1 (1906), 3, 7.

${ }^{42}$ Pavlakis, British Humanitarianism, 56, 184.

${ }^{43}$ Casement, The Congo report, 161.

${ }^{44}$ T.J. Thompson, Light on the Dark Continent: the photography of Alice Seely Harris and the Congo atrocities of the early twentieth century, International Bulletin of Missionary Research (October 2002) 146-9; K. Grant, Christian critics of empire: missionaries, lantern lectures, and the Congo reform campaign in Britain, Journal of Imperial and Commonwealth History 29 (2001) 27-58; Ó. Jacobsen, Daniel J. Danielsen and the Congo: Missionary Campaigns 
and Atrocity Photographs, Troon, Ayrshire, 2015;

https://olijacobsen.files.wordpress.com/2015/03/missionary-campaigns-and-atrocityphotographs.pdf, last accessed 30 April 2018.

${ }^{45}$ Grant, Christian critics of empire, 34.

${ }^{46}$ J. Ryan, Picturing Empire: Photography and the Visualization of the British Empire, Chicago, 1997; D. Campbell, Horrific blindness: images of death in contemporary media, Journal of Cultural Research 8 (2004) 55-74.

${ }^{47}$ P. Hollis (Ed.), Pressure from Without in Early Victorian England, London, 1974.

${ }^{48}$ R. Slade, English missionaries and the beginning of the anti-Congolese campaign in England, Revue belge de Philologie et d'Histoire 33 (1955) 37-73.

${ }^{49}$ Casement to Morel, 23 March 1908, quoted in Ó Síocháin, Roger Casement, 420;

Edmund Morel to Herbert Ward, 10 November 1903, quoted in Ó. Jacobsen, Daniel J.

Danielsen (1871-1916): the Faeroese who changed history in the Congo, Brethren

Historical Review 8 (2012) 18; Louis, Casement and the Congo, 115, 99.

${ }^{50}$ HC Deb. 5 (27 May 1909) c. 1409.

${ }^{51} \mathrm{~J}$. Harris, A Century of Emancipation, London, 1933, 61.

${ }^{52}$ Hansard, House of Lords [HL] Deb. 159 (3 July 1906) c. 1587.

${ }^{53}$ BPP 1914-16 Cd. 7749, xl, 725, Royal Commission on the Civil Service. Appendix to Fifth Report of the Commissioners, 78, q. 38,496

${ }^{54}$ HC Deb. 8 (22 July 1909) c. 666.

${ }^{55}$ HC Deb. 158 (14 June 1906) c. 1136. Sir Edward Grey replaced Lord Lansdowne as Foreign Secretary in December 1905 and brought new energy to the campaign by the British government: Pavlakis, British Humanitarianism, ch. 8.

${ }^{56}$ HC Deb. 8 (22 July 1909) c. 667.

${ }^{57}$ The Congo question, Quarterly Review 204 (January 1906) 61. The foot-dragging is described in Pavlakis, British Humanitarianism, 229-231.

${ }^{58}$ D.C.M. Platt, The Cinderella Service: British Consuls since 1825, Hamden, 1971.

${ }^{59}$ Ascherson writes that the 'Congolese system' was so 'viciously wasteful' of people and trees that in truth: 'It was no more than a prolonged raid for plunder' (King Incorporated, 203).

${ }^{60}$ Ó Síocháin, Roger Casement, 236.

${ }^{61}$ H. Hawkins, Joseph Conrad, Roger Casement, and the Congo reform movement, Journal of Modern Literature 9 (1982) 67.

${ }^{62}$ Ó Síocháin, Roger Casement, 372.

${ }^{63}$ Congo Report, 60.

${ }^{64}$ Notes prepared by Congo government, 14 .

${ }^{65}$ HL Deb. 179 (29 July 1906) c. 408

${ }^{66}$ Ó Síocháin, Roger Casement, 150. On Casement as a precursor of international human rights law, see: B. Kiernan, From Irish famine to Congo reform: nineteenth-century roots of international human rights law and activism, in R. Provost and P. Akhavan (Eds), Confronting Genocide, Dordrecht, 2011, 13-43.

${ }^{67}$ Dudgeon, Black Diaries, 169; A. Mitchell (Ed.), Sir Roger Casement's Heart of Darkness: The 1911 Documents, Dublin, 2003, 224.

${ }^{68}$ HC Deb. 8 (22 July 1909) c. 653.

${ }^{69}$ L. Colley, Britons: Forging the Nation 1707-1837, New Haven, 1992; D. Lambert, White Creole Culture, Politics and Identity during the Age of Abolition, Cambridge, 2005.

${ }^{70}$ HL Deb. 184 (24 February 1908) c. 1287; HL, 24 February, c. 1288.

${ }^{71}$ Congo Report, 26, 44.

${ }^{72}$ A.B. Keith, The Belgian Congo and the Berlin Act, Oxford, 1919, 60. 
${ }^{73}$ Ó Síocháin, Roger Casement, 275.

${ }^{74}$ Ó Síocháin, Roger Casement, 332, 331. From his examination of the manuscript, Ó

Síocháin offers 'peeves' as a possible alternative reading for 'proves'; but this would be ungrammatical and is out of keeping with tone of the remark as a whole.

75 Africa No. 14 (1903), 3.

${ }^{76} 13$ June 1902: Cookey, Britain and the Congo Question, 77, 186.

${ }^{77}$ K. Grant, A Civilised Savagery: Britain and the New Slaveries in Africa, 1884-1926, London, 2005, 65.

${ }^{78}$ BPP 1912-13 Cd. 6266, lxvii, 819, Miscellaneous. No. 8 (1912). Correspondence respecting the Treatment of British Colonial Subjects and Native Indians employed in the Collection of Rubber in the Putumayo District.

${ }^{79}$ Casement to Morel, 5 April 1911, in Mitchell, Casement's Heart of Darkeness, 215;

Casement to Travers Buxton, 18 April 1911, Casement's Heart of Darkness, 255; Casement to Foreign Office, 20 June 1911, Casement's Heart of Darkness, 393, 395.

${ }^{80}$ Casement to William Cadbury, 7 July 1905, quoted in Ó Síocháin, Roger Casement, 430.

${ }^{81}$ Casement to Alice Stopford Green, 20 April 1907, quoted in A. Mitchell (Ed.), The

Amazon Journal of Roger Casement, Dublin, 1997, 280.

${ }^{82}$ Casement to Green, 20 April 1907, 280.

${ }^{83}$ Casement to Hugh Law, 12 April 1905, quoted in Ó Síocháin, Roger Casement, 432.

${ }^{84}$ Casement to John Horgan, 16 February 1914, quoted in Dudgeon, Black Diaries, 428.

${ }^{85}$ D.P. Nally, Human Encumbrances: Political Violence and the Great Irish Famine, Notre Dame, 2011.

${ }^{86}$ Angus Mitchell, 'An Irish Putumayo': Roger Casement's humanitarian relief campaign among the Connemara islanders 1913-14, Irish Economic and Social History 31 (2004) 43, 44. Casement is referring sarcastically to Oliver Cromwell's injunction to Irish people in 1653 that they might go to Hell or Connacht, leaving the rest of Ireland for British settlement. The letter to the Irish Independent was published on 20 May 1913.

${ }^{87}$ Porter, Critics of Empire, 266-75.

${ }^{88}$ Casement, Parnell (6 October 1891), in Casement, Crime Against Europe, 171.

${ }^{89}$ Pavlakis, British Humanitarianism, 16.

${ }^{90}$ S. Holton, Gender difference, national identity and professing History: the case of Alice Stopford Green, History Workshop Journal 53 (2002) 118-127; Green, Irish Nationality, New York, 1911, 14; Ó Síocháin, Roger Casement, 570, 678.

${ }^{91}$ A. Porter, Sir Roger Casement and the international humanitarian movement, Journal of Imperial and Commonwealth History 29 (2001) 64.

${ }^{92}$ Porter, Casement, 72.

${ }^{93}$ R. Kirkland, Rhetoric and (mis)recognitions: reading Casement, Irish Studies Review 7 (1999) 165.

${ }^{94}$ Casement, The keeper of the seas [1911], in Casement, Crime Against Europe, 16-26; 1815-1915: a parallel and a contrast [1915], Crime Against Europe, 143; The balance of power [1913], Crime Against Europe, 28.

${ }_{95}$ A. Mitchell, One Bold Deed of Open Treason: The Berlin Diary of Roger Casement 1914-1916, Sallins, 2010, 164.

${ }^{96}$ Mitchell, One Bold Deed, 32.

${ }^{97}$ Mitchell, One Bold Deed, 179 (entry of 17 March 1916).

${ }^{98}$ Inglis, Casement, 321.

${ }^{99}$ Emmet, Speech from the dock, 49-50.

${ }^{100}$ W.J. McCormack, Robert Emmet and Roger Casement, in A. Dolan, P. Geoghegan, and D. Jones (Eds), Reinterpreting Robert Emmet: Essays on the Life and Legacy of Robert Emmet, 
Dublin, 2007, 219-226.

${ }^{101}$ Mitchell, One Bold Deed, 220.

${ }^{102}$ D. O' Donnell, High treason: the appeal of Roger Casement, in High Treason: Roger Casement (Dublin: Dublin City Gallery The Hugh Lane, 2016) 33.

${ }^{103}$ Dudgeon, Black Diaries, 497.

${ }^{104}$ O’ Donnell, High Treason, 32.

${ }^{105}$ G.H. Knott (Ed.), Trial of Sir Roger Casement, Toronto, 1917, 57, 153, 155, 158, 196.

${ }^{106}$ Dudgeon, Black Diaries, 508.

${ }^{107}$ Knott, Trial, 175.

${ }^{108}$ Ó Síocháin, Roger Casement, 1,032.

${ }^{109}$ G.B. Shaw, The Roger Casement trial, Massachusetts Review 5:2 (1964) 312.

${ }^{110}$ Knott, Trial, 135.

${ }^{111}$ Knott, Trial, 198, 199, 199, 200, 203.

${ }^{112}$ Knott, Trial, 205.

${ }^{113}$ Bass finds the roots of modern interventionist policies in this sort of diplomacy: $G$.

Bass, Freedom's Battle: The Origins of Humanitarian Intervention, New York, 2008.

${ }^{114}$ Royal Commission on the Civil Service, 83, q. 38,589.

${ }^{115}$ M. Barnett, Empire of Humanity: A History of Humanitarianism, Ithaca, 2011.

${ }^{116}$ D. Lambert and A. Lester, Geographies of colonial philanthropy, Progress in Human Geography 28 (2004) 320-341; H. Gilbert and C. Tiffin (Eds), Burden or Benefit? Imperial Benevolence and its Legacies, Bloomington, 2008; R. Skinner and A. Lester, Humanitarianism and empire: new research agendas, Journal of Imperial and Commonwealth History 40 (2012) 729-747.

${ }^{117}$ S.D. Clark, The Land War in Ireland, Cambridge, 1973.

${ }^{118}$ Ó Síocháin, Roger Casement, 695, 727.

${ }^{119}$ I. Tyrrell, Reforming the World: The Creation of America's Moral Empire, Princeton, 2010.

${ }^{120}$ D. Gilmour, Curzon, London, 1994.

${ }^{121}$ F.E. Smith, Idealism in international politics [1923], in Smith, The Speeches of Lord

Birkenhead, London, 1929, 216.

${ }^{122}$ Ó Síocháin, Roger Casement, 826.

${ }^{123}$ J.C. Scott, Weapons of the Weak: Everyday Forms of Peasant Resistance, New Haven, 1985.

${ }^{124}$ Roger Casement no more! Ulster Herald (12 August 1916) 5.

${ }^{125}$ J. Joyce, Ulysses, ed. H.W. Gabler, New York, 1986 [1922], 12:1481-5. The many conflations of Bloom and Casement are discussed in P. Mullen, Ruling passion: James Joyce, Roger Casement, and the bugger's tool, Critical Quarterly 46 (2004) 95-118. 